\title{
EFFECTS OF DIFFERENT SUCROSE LEVELS ON DIGESTIBILITY AND MASTICATION OF HAY AND ON YIELD AND COMPOSITION OF MILK IN DAIRY COW
}

\author{
LiISA SyrJäLÄ \\ University of Helsinki, Department of Animal Husbandry
}

Received July 22, 1970

\begin{abstract}
In the trials two dairy cows were fed on $6 \mathrm{~kg}$ of timothy hay and $0,1,2$ and $4 \mathrm{~kg}$ of pure beet sugar. $\mathrm{Cr}_{2} \mathrm{O}_{3}$ was used as tracer. If the sugar addition to the diet was $1 \mathrm{~kg} / \mathrm{cow} /$ day, there was practically no effect on the digestibility of hay. When the sugar was increased to $2 \mathrm{~kg} /$ cow/day, the digestibility of hay decreased $11.7 \%$-units. In the case of the cell wall complex the corresponding decrease was $17 \%$-units. After having $4 \mathrm{~kg}$ sugar/day both cows stopped eating completely. A $2 \mathrm{~kg}$ sugar addition depressed also the mastication in the alimentary tract, whereas $1 \mathrm{~kg}$ of sugar had only a slight effect on it. The dry matter of milk decreased by about $1 \%$-units when $1 \mathrm{~kg}$ sugar was given to the cows the decrease being in the milk fat content. $2 \mathrm{~kg}$ of sugar produced no further effect. The sugar additions to the diet did not affect the contents of milk protein, ash and lactose.
\end{abstract}

The digestibility of feeds in ruminants depends to a great extent on the activity of the rumen micro-organisms. These microbes obtain energy mainly by digesting the insoluble carbohydrates (cellulose, hemicellulose) of the diet. If, however, other more easily fermentable nutrients, such as sugars, are available, they attack these instead. The effect of sugar additions on the utilization of the diet is not well known and more experiments are needed in this field.

Many experiments have been made using molasses as a supplemental energy source in feeds for ruminants. Its effect on the digestibility of roughage has varied with the amount of molasses and the composition of the diet (Williams 1925, Briggs 1937, Briggs and Heller 1940 and 1943, Bray et al. 1945, Bohman et al. 1954, Komkris et al. 1965, Martin, JR. and Wing 1966). Pure sugar as a source of supplemental energy has been used in only a few experiments. Glucose, added to rations containing varying percentages of protein, has been found to decrease the digestibility of the more complex polysacharides, cellulose and hemicellulose (Mrtchell and Hamiton 1940), and also of all the nutrients of a basal ration (Hamilton 1942). Faecal $\mathrm{N}$ losses were greatest when starch and glucose were included in the diets (Oltjen and Putman 1966) which explains why the addition of sugar affected the apparent but not the true digestibility of protein (Hamilton 1942). 
However, KuriLov (1965) found that a ration containing $2-3 \mathrm{~g}$ sugar/kg live weight for sheep and $3-5 \mathrm{~g} / \mathrm{kg}$ live weight for cattle stimulated rumen fermentation and the utilization of feed N. According to the investigations of KrJukOv (1965), the addition of $3 \mathrm{~g}$ sugar $/ \mathrm{kg}$ live weight increased the fermentative process in the rumen of steers.

Studies on the effect of the sugar level of the ration on the lactation performance have revealed an increase in milk production (HufFMAN and Duncan 1944) and a linear increase in the solids-corrected milk yield with the addition of increasing amounts of sucrose (Kellogg and Owen 1969). The effect of sugar on the fat, protein and lactose content of milk has varied with the level of sugar in the ration and the composition of the diet (Broster et al. 1964, Fisher and Elliot 1966, Kurilov et al. 1966, Kellog 1969).

The purpose of this work is to study how different amounts of sugar in the diet affect the digestibility of the feed and the efficiency of mastication. The word mastication in this work indicates the mincing of food in the whole alimentary tract. Attention has also been paid to the effect of sugar on the yield and composition of the milk. Timothy hay was the only feed used, and the sugar was pure beet sucrose.

\section{Experimental procedure}

Two lactating Ayrshire cows were used in this experiment. The cows, Meno and Mutina, were of the same age and size. Both cows were at the end of their lactation period.

During the experimental periods the cows received $6 \mathrm{~kg}$ of timothy hay as the basal ration and different quantities of sucrose (Table 1). Each experimental period lasted 10 days, $\mathrm{Cr}_{2} \mathrm{O}_{3}$ was used as the indicator.

Table 1. The diet of the cows in the different experimental periods.

\begin{tabular}{cccr}
\hline $\begin{array}{c}\text { Experimental } \\
\text { period }\end{array}$ & $\begin{array}{c}\text { Hay } \\
\mathrm{kg} / \text { day }\end{array}$ & $\begin{array}{c}\text { Sucrose } \\
\text { addition kg/day }\end{array}$ & $\begin{array}{c}\text { Total sugars in } \\
\text { ration }\end{array}$ \\
\hline & & & 385 \\
0 & 6 & 1.000 & 1.385 \\
1 & 6 & 2.000 & 2.385 \\
3 & 6 & 4.000 & 4.385
\end{tabular}

1) The sugar content of timothy hay was $7.6 \%$ of the dry matter.

The cows were fed twice a day. Each time they were first allowed to eat some of their $3 \mathrm{~kg}$ hay bundles and the $10 \mathrm{~g} \mathrm{Cr}_{2} \mathrm{O}_{3}$ capsules were then pushed directly into their throats so that they swallowed them whole. Later, when the sugar periods began, the cows first received the sugar rations dissolved in water and were given the hay rations and $\mathrm{Cr}_{2} \mathrm{O}_{3}$ capsules immediately afterwards. Water was freely available.

Both cows were healthy during the experiment and ate their rations well. When the level of sugar was $4000 \mathrm{~g} /$ day, both cows stopped eating sugar and their hay consumption also diminished. The latter recovered in a few days, but the cows continued to refuse the sugar. So the actual experiment came to an end after Period 2. 
The cows were weighed at the beginning of every experimental periods. There were only small varitions in the weights during the experiment. The live weights of the cows at the beginning of the experimental periods was as follows:

\begin{tabular}{ccc}
$\begin{array}{c}\text { experimental } \\
\text { period }\end{array}$ & \multicolumn{2}{c}{ live weights kg } \\
0 & cow Meno & cow Mutina \\
1 & 549 & 478 \\
2 & 524 & 457 \\
3 & 523 & 447 \\
& 534 & 458
\end{tabular}

\section{Results and discussion}

Digestibility of hay. Several faeces samples of the last day of each experimental period were collected and combined for use in the digestibility investigations. The hay and faeces samples were dried at $50^{\circ} \mathrm{C}$ in a vacuum oven and ground in the Wiley mill using a 40 -mesh $(0.42 \mathrm{~mm})$ screen. From these samples were determined dry matter, ash, crude protein and $0.05 \mathrm{~N}$ acid fibre by the method of PALOHEImo (1945) with a small modification. Water-soluble sugars and cell wall substances were determined according to the method of SALo (1965), the determinations of the latter being obtained by taking the sum of their chemical fractions. The cell wall complex was determined from the hay sample by the method of PALOHEImo and Vainio (1965) and from the fresh faeces samples by the unpublished method of Paloheimo and Syrjälä (See Pulliainen, Palohermo and SYrJÄLÄ 1968, p. 8). The cell wall complex is obtained from a certain crude fraction (F-fraction) by extraction with $80 \%(\mathrm{v} / \mathrm{v})$ ethanol and by using ash and crude protein corrections. The crude fibre of the hay was determined by the Weende method using the modification of Puranen and Tomula (ref. Palohermo 1969). The $\mathrm{Cr}_{2} \mathrm{O}_{3}$ content of the faeces was determined according to Palohermo and Palohermo (1935).

Tables 2, 3 and 4 show the results of the analysis, the digestibility percentages and the values for digestible nutrients obtained for the different experimental periods.

In compiling the four columns in the right-hand part of Table 2, it was supposed that the exogenous organic matter of the faeces equals the organic matter of the F-fraction. This being so, the exogenous crude protein of the faeces equals the crude protein of the $\mathrm{F}$-fraction. Further the exogenous $\mathrm{N}$-free organic cell enclosure substances equal the exogenous $\mathrm{N}$-free organic matter minus the cell wall complex.

The digestibility values in Table 3 have been calculated for the hay ration alone, since the added sugar is assumed to have been completely digested. Thus all changes in the digestibility of the components of the hay can be attributed directly to the added sugar. If the digestibility values were calculated for the whole ration, including the sugar supplements, the values obtained would be very deceptive, because the proportion of sugar in the rations is very high: in Period 1 about $16 \%$ and in Period 2 about $28 \%$.

The digestibility values in the left-hand part of Table 3 show the apparent digestibility of the hay, apart from the values of the cell wall complex, which are true. The values in the right-hand part show the true digestibility.

Table 3 shows that when $1 \mathrm{~kg}$ sugar was added to the diet (Period 1), the digestibility of the nutrients in timothy hay differed very little from their digestibility in Period 0 
when the cows received only hay. When the amount of sugar was increased to $2 \mathrm{~kg}$ (Period 2), the digestibility values decreased considerably. In Periods 0 and 1 the average digestibility values of the dry matter of hay are practically the same, 62.1 and $61.6 \%$, but in Period 2 the value is as low as 50.3 per cent. The results are similar in the case of the organic matter and the $\mathrm{N}$-free organic matter. The digestibility of the cell wall complex is $51.7 \%$ in Period 2, while in Period 0 it is $70.7 \%$ and in Period $169.0 \%$. The digestibility of the cellulose shows a marked decrease in Period 2 being $24.1 \%$ units lower than in Period 0, while in Period 1 it is only $3.2 \%$-units lower than in Pericd 0. The digestibility values of the neutral sugar anhydrides of the hemicellulose fraction and the $0.05 \mathrm{~N}$ acid fibre also decrease by about $20 \%$-units from Periods 0 and 1 to Period 2. The true digestibility values of the crude protein and the $\mathrm{N}$-free organic cell enclosure substances are very high and the differences between the periods are small; in the former case the values are $94.6,94.6$ and $93.7 \%$, and in the latter case $93.5,93.3$ and $93.8 \%$ in Periods 0,1 and 2, respectively. The true digestibility values of the organic matter and the $\mathrm{N}$-free organic matter are of the same order in Periods 0 and 1 , but in Period 2 the values are more than $10 \%$-units lower. A comparison of the true digestibility with the apparent digestibility shows that the former is much higher than the latter, in some cases about twice as high.

Table 2. The dry matter and chemical components of hay and faeces as percentages of dry weight in different experimental periods.

\begin{tabular}{|c|c|c|c|c|c|c|c|c|c|c|c|c|c|c|}
\hline & \multirow[b]{2}{*}{ 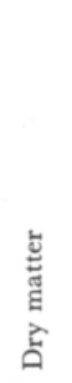 } & \multirow[b]{2}{*}{ 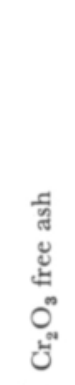 } & \multirow[b]{2}{*}{ 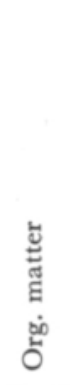 } & \multirow[b]{2}{*}{ 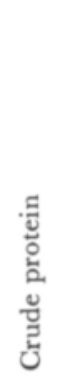 } & \multirow[b]{2}{*}{ 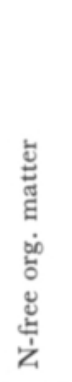 } & \multirow[b]{2}{*}{ 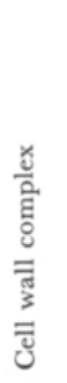 } & \multirow[b]{2}{*}{ 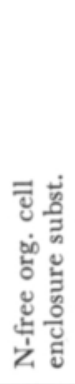 } & \multicolumn{3}{|c|}{$\begin{array}{l}\text { Cell wall subst. (SALO's } \\
\text { meth.) } \\
\text { Hemicellulose }\end{array}$} & \multicolumn{4}{|c|}{ Exogenous $^{1}$} \\
\hline & & & & & & & & 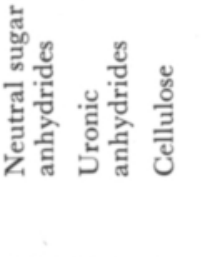 & 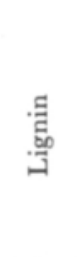 & స్ & 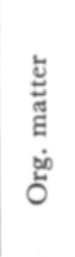 & 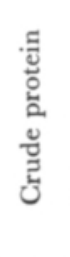 & 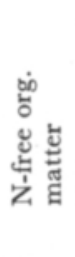 & 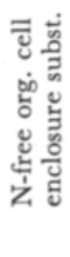 \\
\hline $\begin{array}{l}\text { Timothy hay } \\
\text { Faeces }\end{array}$ & 84.4 & 8.4 & 91.6 & 11.1 & 80.5 & 62.0 & 18.553 .9 & $20.94 .5 \quad 25.1$ & 8.1 & 58.6 & 91.6 & 11.1 & 80.5 & 18.5 \\
\hline \multicolumn{15}{|l|}{ Cow Meno } \\
\hline Period 0 & 19.8 & 13.1 & 85.7 & 12.3 & 73.4 & 45.5 & 27.941 .0 & $\begin{array}{lll}16.3 & 4.0 & 16.5\end{array}$ & 18.9 & 55.7 & 49.9 & 1.7 & 48.2 & 2.7 \\
\hline " 1 & 18.0 & 11.1 & 87.7 & 14.5 & 73.2 & 47.6 & 25.643 .8 & $\begin{array}{lll}17.0 & 3.9 & 17.8\end{array}$ & 16.9 & 55.6 & 52.1 & 1.7 & 50.4 & 2.8 \\
\hline " 2 & 17.0 & 8.2 & 91.0 & 10.6 & 80.4 & 58.4 & $22.0 \quad 55.3$ & $21.54 .2 \quad 24.4$ & 15.6 & 65.7 & 63.1 & 1.6 & 61.5 & 3.1 \\
\hline \multicolumn{15}{|c|}{ Cow Mutina } \\
\hline Period 0 & 19.3 & 11.8 & 87.3 & 12.3 & 75.0 & 49.7 & 25.344 .0 & 17.93 .818 .1 & 19.4 & 59.2 & 54.6 & 1.5 & 53.2 & 3.4 \\
\hline$n 1$ & 17.8 & 9.6 & 89.5 & 12.7 & 76.8 & 51.6 & 25.246 .8 & $\begin{array}{lll}18.9 & 4.3 & 20.4\end{array}$ & 18.5 & 62.1 & 56.6 & 1.5 & 55.1 & 3.5 \\
\hline$m \quad 2$ & 17.7 & 7.7 & 91.5 & 10.9 & 80.6 & 62.3 & 18.357 .0 & 21.94 .226 .5 & 14.3 & 66.9 & 65.2 & 1.2 & 64.0 & 1.7 \\
\hline
\end{tabular}

The decreased digestibility of the cell wall substances in Period 2 is probably due to the fact that plenty of sugars were available for the microbes in the rumen making the conditions more unfavourable for the digestion of the cell wall constituents. In Period 1, 
when the sugar addition was only $1 \mathrm{~kg} /$ day, the situation was different as is shown by the digestibility values. The optimum sugar level appears to have been less than $2 \mathrm{~kg} / \mathrm{day}$.

The animals used the sugar supplement very well. Only small amounts of sugar were found in the faeces. Percentages of water-soluble sugars in dry matter of faeces in the different experimental periods was as follows:

$\begin{array}{ccc}\text { period } & \text { cow Meno } & \text { cow Mutina } \\ 0 & 0.4 & 0.4 \\ 1 & 0.5 & 0.6 \\ 2 & 0.7 & 0.7\end{array}$

Table 3. The digestibility percentages of the dry matter of hay and its components in different experimental periods.

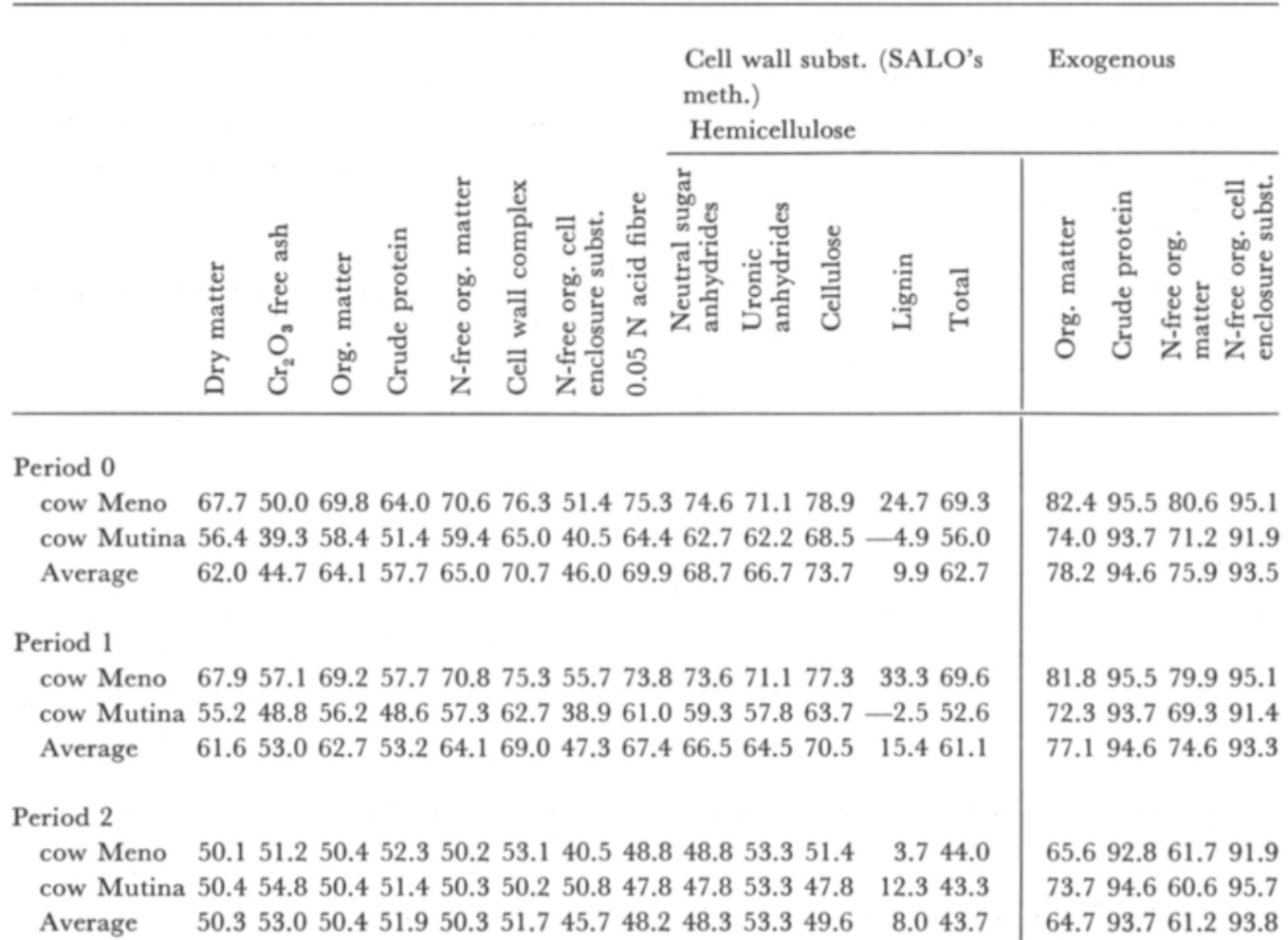

Efficiency of the mastific ation. The efficiency of the mastication of hay when different amounts of sugar were added was investigated by sieve fractionation of the faeces (Palohermo, Syrjälä and Vainio 1968). The results are shown in Table 5.

The fractions remaining on the sieves consist of the exogenous part of the faeces (Palohermo 1962, Palohermo 1966). These fractions mainly comprise plant cell wall substances derived from the food. The fraction passing through all the sieves consists largely of endogenous and bacterial material and probably also contains cell wall particles small enough to pass through the $0.1 \mathrm{~mm}$ sieve. 
Table 4. The amounts of digestible nutrients expressed as $\mathrm{g}$ per $100 \mathrm{~g}$ of dry matter of hay, in different experimental periods.

\begin{tabular}{|c|c|c|c|c|c|c|c|c|c|c|c|c|c|}
\hline & \multirow[b]{2}{*}{ 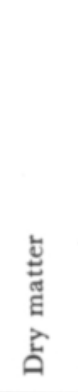 } & \multirow[b]{2}{*}{ 岳 } & \multirow[b]{2}{*}{ 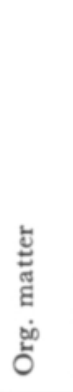 } & \multirow[b]{2}{*}{ 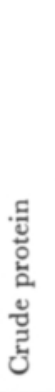 } & \multirow[b]{2}{*}{ 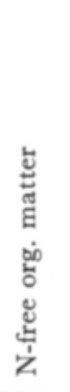 } & \multirow[b]{2}{*}{ 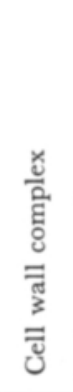 } & \multirow[b]{2}{*}{ 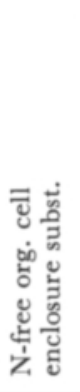 } & \multirow[b]{2}{*}{ 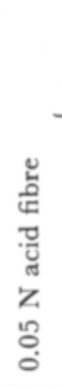 } & \multicolumn{2}{|c|}{$\begin{array}{l}\text { Cell wall subst. (SALO's } \\
\text { meth.) } \\
\text { Hemicellulose }\end{array}$} & \multicolumn{3}{|c|}{ Exogenous } \\
\hline & & & & & & & & & 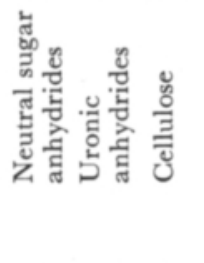 & 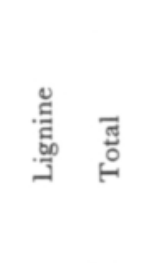 & 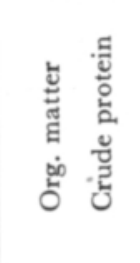 & 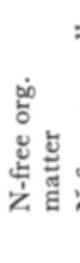 & 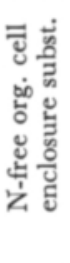 \\
\hline \multicolumn{14}{|l|}{ Period 0} \\
\hline cow Meno & 67.7 & 4.2 & 63.9 & 7.1 & 56.8 & 47.3 & 9.5 & 40.6 & $\begin{array}{lll}15.6 & 3.2 & 19.8\end{array}$ & 2.040 .6 & 75.510 .6 & 64.9 & 17.6 \\
\hline cow Mutina & 56.4 & 3.3 & 53.5 & 5.7 & 47.8 & 40.3 & 7.5 & 34.7 & $\begin{array}{lll}13.1 & 2.8 & 17.2\end{array}$ & -0.432 .8 & $\begin{array}{lll}67.8 & 10.4\end{array}$ & 57.3 & 17.0 \\
\hline Average & 62.1 & 3.8 & 58.7 & 6.4 & 52.3 & 43.8 & 8.5 & 37.7 & $\begin{array}{llll}14.4 & 3.0 & 18.5\end{array}$ & 0.836 .7 & $\begin{array}{ll}71.7 & 10.5\end{array}$ & 61.1 & 17.3 \\
\hline \multicolumn{14}{|l|}{ Period 1} \\
\hline cow Meno & 67.9 & 4.8 & 63.4 & 6.4 & 57.0 & 46.7 & 10.3 & 39.8 & $\begin{array}{lll}15.4 & 3.2 & 19.4\end{array}$ & 2.740 .8 & $74.9 \quad 10.6$ & 64.3 & 17.6 \\
\hline cow Mutina & 55.2 & 4.1 & 51.5 & 5.4 & 46.1 & 38.9 & 7.2 & 32.9 & $\begin{array}{lll}12.4 & 2.6 & 16.0\end{array}$ & -0.230 .8 & 66.210 .4 & 55.8 & 16.9 \\
\hline Average & 61.6 & 4.5 & 57.5 & 5.9 & 51.6 & 42.8 & 8.8 & 36.4 & $13.9 \quad 2.9 \quad 17.7$ & 1.335 .8 & $70.6 \quad 10.5$ & 60.1 & 17.3 \\
\hline \multicolumn{14}{|l|}{ Period 2} \\
\hline cow Meno & 50.1 & 4.3 & 46.2 & 5.8 & 40.4 & 32.9 & 7.5 & 26.3 & $\begin{array}{lll}10.2 & 2.4 & 12.9\end{array}$ & 0.325 .8 & $\begin{array}{ll}60.1 & 10.3\end{array}$ & 49.8 & 17.0 \\
\hline cow Mutina & 50.4 & 4.6 & 46.2 & 5.7 & 40.5 & 31.1 & 9.4 & 25.6 & $\begin{array}{llll}10.0 & 2.4 & 12.0\end{array}$ & 1.025 .4 & $\begin{array}{lll}59.3 & 10.5\end{array}$ & 48.8 & 17.7 \\
\hline Average & 50.3 & 4.5 & 46.2 & 5.8 & 40.5 & 32.0 & 8.5 & 26.0 & $10.12 .4 \quad 12.5$ & 0.725 .6 & $\begin{array}{ll}59.7 & 10.4\end{array}$ & 49.3 & 17.4 \\
\hline
\end{tabular}

Table 5 shows that the addition to sugar ot the hay diet decreased the efficiency of mastication of both cows. The decrease was greater with $2 \mathrm{~kg}$ of sugar than with $1 \mathrm{~kg}$.

$\mathrm{Yi}$ id and composition of milk. Analyses were made of milk samples taken in the last three days of each experimental period. The dry matter, ash, fat and protein were determined. The lactose content was calculated by subtracting ash, fat and protein from the dry matter. The $\mathrm{N}$-content of milk protein being about $15.7 \%$, the coefficient 6.37 was used in the calculation of the milk protein.

Table 5. Percentages of dry matter of faeces remaining on different sieves.

\begin{tabular}{|c|c|c|c|c|c|c|c|c|c|}
\hline \multirow{2}{*}{$\begin{array}{c}\text { Experimental } \\
\text { period }\end{array}$} & \multicolumn{3}{|c|}{$\begin{array}{l}\text { Remaining on } 2,1 \\
\text { and } 0.5 \mathrm{~mm} \text { sieves }\end{array}$} & \multicolumn{3}{|c|}{$\begin{array}{c}\text { Remaining on } 0.1 \\
\text { mm sieve }\end{array}$} & \multicolumn{3}{|c|}{$\begin{array}{c}\text { Passing through } \\
\text { all sieves }\end{array}$} \\
\hline & $\begin{array}{c}\text { cow } \\
\text { Meno }\end{array}$ & $\begin{array}{c}\text { cow } \\
\text { Mutina }\end{array}$ & $\begin{array}{l}\text { Aver- } \\
\text { age }\end{array}$ & $\begin{array}{c}\text { cow } \\
\text { Meno }\end{array}$ & $\begin{array}{c}\text { cow } \\
\text { Mutina }\end{array}$ & $\begin{array}{l}\text { Aver- } \\
\text { age }\end{array}$ & $\begin{array}{l}\text { cow } \\
\text { Meno }\end{array}$ & $\begin{array}{c}\text { cow } \\
\text { Mutina }\end{array}$ & $\begin{array}{l}\text { Aver- } \\
\text { age }\end{array}$ \\
\hline 0 , hay $6 \mathrm{~kg}$ & 14.4 & 17.4 & 15.9 & 32.5 & 31.9 & 32.2 & 53.1 & 50.7 & 51.9 \\
\hline $\begin{array}{c}\text { 1, hay } 6 \mathrm{~kg} \\
\text { sugar } 1 "\end{array}$ & 18.6 & 18.4 & 18.4 & 31.9 & 34.0 & 33.0 & 49.5 & 47.7 & 48.6 \\
\hline $\begin{array}{c}2 \text {, hay } 6 \mathrm{~kg} \\
\text { sugar } 2 \mathrm{~m}\end{array}$ & 23.8 & 24.2 & 24.0 & 37.7 & 39.8 & 38.8 & 38.5 & 36.0 & 37.2 \\
\hline
\end{tabular}


Table 6. Average yields and composition of milk in the different periods.

\begin{tabular}{|c|c|c|c|c|c|c|c|}
\hline \multirow[t]{2}{*}{ Period } & \multirow{2}{*}{$\begin{array}{c}\text { Name of } \\
\text { cow }\end{array}$} & \multirow{2}{*}{$\begin{array}{c}\text { Milk } \\
\text { kg/day }\end{array}$} & \multicolumn{5}{|c|}{ Composition of milk (\%) } \\
\hline & & & Dry matter & Ash & Fat & Protein & Lactose \\
\hline \multirow{3}{*}{0} & Meno & 5.3 & 14.5 & 0.7 & 5.5 & 4.0 & 4.4 \\
\hline & Mutina & 6.6 & 14.2 & 0.7 & 5.7 & 3.5 & 4.3 \\
\hline & Average & 6.0 & 14.4 & 0.7 & 5.6 & 3.8 & 4.3 \\
\hline \multirow{3}{*}{1} & Meno & 4.3 & 13.9 & 0.8 & 4.8 & 4.2 & 4.2 \\
\hline & Mutina & 6.2 & 12.8 & 0.7 & 4.6 & 3.4 & 4.1 \\
\hline & Average & 5.3 & 13.4 & 0.8 & 4.7 & 3.8 & 4.1 \\
\hline \multirow{3}{*}{2} & Meno & 3.3 & 14.2 & 0.8 & 5.0 & 4.4 & 4.0 \\
\hline & Mutina & 5.6 & 12.7 & 0.7 & 4.4 & 3.6 & 4.0 \\
\hline & Average & 4.5 & 13.5 & 0.8 & 4.7 & 4.0 & 4.0 \\
\hline
\end{tabular}

Table 6 shows the average yield and the composition of the milk in the different experimental periods. The milk yields decreased slowly over the three periods. This decrease normally occurs when the cows are approaching the end of their lactation period and the effect of differences in the feeding is probably quite small. But the variations in the composition of the milk could depend on the feeding. Table 6 shows that the dry matter of milk is $14.4 \%$ in Period 0 . In Period 1 it has decreased by $1 \%$-unit resulting from the corresponding decrease in fat content. This decrease can be attributed to the addition of sugar, because with a normal diet the dry matter of cow milk increases towards the end of the lactation period. In Period 2 there is no further decrease. It should be noted that the lactose content of the milk did not increase in spite of the addition of sugar to the ration and there was in fact a small decrease. The ash and protein contents of the milk in the different periods remained practically unaltered.

A cknowledgements. I wish to express my thanks to Professor emeritus Lauri Paloheimo for his valuable advice given during the course of the work, and to Miss Hilkka Wathen for the technical assistance. My thanks are also due to Suomen Sokeri Oy which presented the sugar for the experiments.

\section{REFERENCES}

Bohman, V. R., Trimberger, W. G., Loosli, J. K. \& Turk, L. K. 1954. The utilization of molasses and urea in the rations of growing dairy cattle. J. Dairy Sci. 37: 284-293.

Bray, C. I., Snell, M. G., Morrison, F. L. \& Jackson, M. E. 1945. Feeding blackstrap molasses to fattening steers. La. Bull. No. 394.

Briggs, H. M. 1937. The effect of molasses on the digestibility of a lamb fattening ration. Proc. Am. Soc. an. Prod. 1937: 145.

— - \& Heller, V. G. 1940. The effect of adding blackstrap molasses to a lamb fattening ration. J. Agr. Res. 60: 65 .

— - 1943. Effect of adding blackstrap molasses, potassium salts, sucrose and corn syrup to a lambfattening ration. J. Agr. Res. 67: 359-367.

Broster, W. H., Sutton, J. D., \& Tuck, V.J. 1964. Effect on milk production of addition of large amounts of sucrose to the diet. Univ. Reading, Nat. Inst. Res. Dairying. Shinfield, Berkshire, England. Ann. Rep., 1964: 53.

Fisher, L. J., \& Elliot, J. M. 1966. Effect of intravenous infusion of propionate or glucose on bovine milk composition. J. Dairy Sci. 49: 826-829. 
Hamiton, T. S. 1942. The effect of added glucose upon the digestibility of protein and fiber in rations for sheep. J. Nutr. 23: 101-110.

Huffman, C. F. \& Duncan, C. W. 1944. The nutritive value of Alfalfa hay. II. Starch and glucose as supplements to an all Alfalfa hay ration. J. Dairy Sci. 27: $821-833$.

Kellogg, D. W. 1969. Influence of sucrose on rumen fermentation pattern and milk fat content of cows fed a high-grade ration. J. Dairy Sci. 52: 1601-1604.

- - \& OWEN, F. G. 1969. Relation of ration sucrose level and grain content to lactation performance and rumen fermentation. J. Dairy Sci. 52: 657-662.

Komkris, T., Stanley, R. W. \& Morita, K. 1965. Effects of feed containing molasses fed separately and together with roughage on digestibility of rations, volatile fatty acids produced in rumen, milk production, and milk constituents. J. Dairy Sci. 48: 714 -719.

KRJukov, B. 1965. Einfluss eines verschiedenen Zuckergehaltes in der Ration auf die fermentation Vorgänge im Pansen - IX Mendelcevskij S-ezd obscej i prikladmoj chimii. 1965 Nr. 3 S. 262 (Ref. Landw. Zentralbl. III 1966, p. 1985).

Kurilov, N. V., Masloboev, A. YA. \& Sevast'yanova, N. A. 1966. Level of rumen fermentation and utilization of feed $\mathrm{N}$ by cows with feeds rich in starch or sugar included in the ration. Trudy vses. nauchno-issled. Inst. Fiziol. Biokhim. sel'. -khoz. Zhivot. 2: 221-34.

Martin, Jr. \& Wing, J. M. 1966. Effect of molasses level on digestibility of a high concentrate ration and on molar proportions of volatile fatty acids produced in the rumen of dairy steers. J. Dairy Sci. 49: $846-849$.

Mrtchell, H. H. \& Hamilton, T. S. 1940. The utilization by calves of energy in rations containing different percentages of protein and in glucose supplement. J. Agr. Res. 61: 847-864.

Oltjen, R. R. \& Putnam, P. A. 1966. Plasma amino acids and nitrogen retention by steers fed purified diets containing urea or isolated soy protein. J. Nutrition 89: 385-391.

Palohermo, L. 1945, Determination of total quantity of cell wall constituents in foods and feeds (Preliminary report). J. Scient. Agric. Soc. Finn. 17: 19-21.

— - 1962. Food Analysis and the Evaluation of Foods. Nord. jordbruksforsk. 44: $78-86$.

- — 1966. Some remarks on the digestion trials. World Rewiew Anim. Prod. 2: 86—91.

—— 1969. Weender Analyse. Handb. Tierernäh. 1: 164-171.

Paloheimo, L. \& Palohermo, I. 1945. Eine photometrische Methode zur Bestimmung der $\mathrm{Cr}_{2} \mathrm{O}_{3}$ bei Verdaulichkeitsuntersuchungen nach sog. quantitativen Indikatorverfahren. Tierernahrung 7 : $317-324$.

—”- \& VArnio, K. A. 1965. Determination of the complex of cell wall substances in plant products. J. Scient. Agric. Soc. Finn. 37: 305-312.

—”- Syrjälä, L. \& Vainio, K. A. 1968. Studies on the faeces. J. Scient. Agric. Soc. Finn. 40: 237-246.

Pulliainen, E., Palohermo, L. \& Syrjälä, L. 1968. Digestibility of blueberry stems (Vaccinium myrtillus) and cowberries (Vaccinium vitis-idea) in the willow grouse (Lagopus lagopus). Ann. Acad. Scient. Fenn. Series A. IV Biologica 126: 1-14.

SAlo, M-L. 1965. Determination of carbohydrate fractions in animal foods and faeces. Acta Agr. Fenn. 105: $1-102$.

Wrlliams, P. S. 1925. The effect of cane molasses on the digestibility of a complete ration fed to dairy cows. J. Dairy Sci. 8: 94.

\title{
SELOSTUS
}

REHUANNOKSEEN LISÄTYN SOKERIN VAIKUTUKSESTA REHUN SULAVUUTEEN JA HIENONTUMISEEN SEKÄ MAIDON MÄÄRÄÄN JA KOOSTUMUKSEEN LYPSYLEHMÄLLÄ

\author{
LIISA SYRJÄLÄ
}

\section{Helsingin yliopiston kotieläintieteen laitos}

Suoritetun tutkimuksen tarkoituksena oli selvittää, miten eri suuret sokerimäärät vaikuttavat runsaasti kettoaineita sisältävän rehun sulavuuteen ja hienontumiseen. Samalla myöskin tarkkailtiin, aiheuttaako 
jatkuvasti tehostettu sokeriruokinta muutoksia maidon määrässä ja koostumuksessa.

Koe suoritettiin kahdella lehmällä, jotka saivat $6 \mathrm{~kg}$ timoteiheinää sekä $0,1,2 \mathrm{ja} 4 \mathrm{~kg}$ puhdasta sokeria vuorokaudessa. Johtoaineena sulavuuskokeissa käytettiin kromioksidia.

Jos rehuannoksen sokerilisä oli lehmää kohti $1 \mathrm{~kg} / \mathrm{vrk}$, ei vielä seurannut sanottavaa sulavuuden heikentymistä verrattaessa tapaukseen, jossa lehmä heinän tisäksi ei saanut ollenkaan sokeria. Kun sokerilisä nostettiin 2 kiloon/lehmä/vrk, laski heinän sulavuus keskimäärin $11.7 \%$-yksikköä. Kettoaineiden kohdalla tämä aleneminen oli 17 \%-yksikköä. Nostettaessa sokerilisä 4 kiloon/lehmä/vrk, lakkasivat molemmat lehmät kokonaan syömästä. $2 \mathrm{~kg}$ !n sokerilisäys alensi myös ruoansulatuskanavassa tapahtuvaa rehun hienontumista huomattavasti, kun taas yhdestä sokerikilosta johtuva vaikutus oli vain vähäinen.

Sokeriruokinnan vaikutus maidossa näkyi kuiva-ainepitoisuuden laskuna. Tämä aleneminen oli sama kuin maidon rasvapitoisuudessa tapahtunut lasku eli $1 \%$-yksikkö. Vaikutus ilmeni jo 1 kg:n sokerilisäyksellä eikä 2 kg lisäys enää enentänyt maidon kuiva-aine- ja rasvapitoisuuden laskua. Maidon valkuais-, tuhka- ja sokeripitoisuuteen ei rehuannokseen lisätty sokeri vaikuttanut. 